\title{
Enhancing Customer Retention through Electronic Service Delivery Channels in the Nigerian Banking Industry
}

\author{
A. P. Olannye ${ }^{1}$, S. E. Dedekuma ${ }^{1}$ \& E. H. Ndugbe ${ }^{1}$ \\ ${ }^{1}$ Department of Business Administration and Marketing, Delta State University, Abraka, Nigeria \\ Correspondence: Dr. A. P. Olannye, Department of Business Administration and Marketing, Faculty of Management \\ Sciences, Delta State University, Abraka, Nigeria. Tel: 234-80-3309-7190.
}

Received: June 20, 2017

Accepted: July 6, 2017

Online Published: July 31, 2017

doi:10.5430/ijba.v8n5p57

URL: https://doi.org/10.5430/ijba.v8n5p57

\begin{abstract}
Successful customer retention consists of more than just giving the customer what they expect. Electronic service delivery channels have become a means through which banks achieve their objectives of business renewal and providing effective and efficient services. The main objective of this study is to examine the effect of electronic service delivery channels on customer retention in the Nigerian banking industry. The study made use of a sample of 235 employees from some selected banks in Asaba Metropolis in Delta State, Nigeria. Cross sectional survey research design method was adopted, and the statistical tools used comprised simple percentage, correlation and multiple regression analysis. Findings showed that point of sales service exhibited the relatively highest positive effect on customer retention. It was also revealed that online banking service, point of sales service and mobile banking have significant relationships with customer retention. The study concluded that the demand for POS technology seems currently high, however banks are now taping into this opportunity by making POS available at all times, so as to reduce queuing time in the bank and give customers convenience and control. It is therefore recommended that banks should collaborate with internet service providers because it will enable banks to better control quality of service as well as enhance user's accessibility.
\end{abstract}

Keywords: electronic service delivery channels, online banking services, point of sales service, mobile banking service, customer retention

\section{Introduction}

The demand for better-quality services, competitiveness, cost reduction and flexibility seems to be faced by Nigerian banks. The Nigeria Banking Industry has witnessed an amazing growth in terms of number of branches, total asset, deposit base and volume of loans and advances, especially since the deregulation of the sector in the recent past years. In a relatively new delivery channel application with the platforms geared towards overcoming challenges in the traditional banking system. In the Nigerian banking industry today, only sixteen commercial banks meet up with the central banks directives. Therefore these sixteen branches are operating in Asaba, Delta State excluding the micro finance banks.

While addressing these demands, banks seem to be experiencing unprecedented advances in technology, a changing population workforce, new skills requirements, enhanced capabilities for partnerships and new lines of communication. As a result, these banks have been involved in a fundamental restructuring. The banking sector has already begun implementing new approaches to doing business. They appear to have devised alternative means of service delivery. As a matter of fact, vital lessons could be learned from their experiences.

Riding on the bank of the ever evolving technological advancements to address these services challenges, banks developed and adopted the use of electronic service delivery channels for efficient delivery of their various services. Mwangi (2007), stated that alternative service delivery is changing the way companies work. It seems to open up a vast array of new solutions to service delivery issues. By using electronic service delivery channels, business organizations especially banks appear to be realizing the benefits of focusing their businesses on the things they do best while allowing other firms to deliver other activities and functions they could not do best. Electronic service delivery channels could be a way in which the organizations achieve their objectives of business renewal and providing effective and efficient services. According to Ovum Analyst Findings (2013), alternative service delivery could also be a means of continuing to provide some services or products, which have been provided traditionally by 
the other firms through or in partnership with organizations outside the organization. These products or services may be provided either to the public or to users within the organization.

Customer retention is an intensely held commitment to re-patronize a preferred service continuously in the future, thereby leading to repetitive purchasing of the same brand, despite conditional influences and marketing efforts. Customer retention has become the major agenda for banks who emphasize on sustaining a productive relationship with customers, besides functioning as a main instrument to generate financial gains (Kumar, Andrew and Robert, 2007). The retained customers most times do not mind paying a little higher prices and look forward for discounts as compared to the new customers (Ang and Buttle, 2006). Successful customer retention consists of more than giving the customer what they need. Acquiring loyal advocates of the brand might connote exceeding customer expectations.

Electronic service delivery channels could also be known as alternative delivery initiatives or as alternative program delivery. According to Mwangi (2007), using alternative service delivery, providers ranging from public agencies to private sector companies will be able to provide services or products to Nigerians and to the public, while making the best use of scarce resources. In the Nigerian Banking industry today, the use of electronic service delivering channels appears to be competitive. All the banks in the country seem to be using related electronic delivering service channels to ease customers the stress of queuing up in the banking halls. Such service delivery as online banking, POS and mobile banking among others are being used in the banking sector.

Tele-banking has lots of gains for both banks and customers. As far as the customers are concerned, it provides expanded access, convenience and vital time saving. On the other hand, from the banks' point of view, the costs of delivering telephone-based services are considerably lesser than those of branch based services. It has almost all the effects on productivity of ATMs, despite that it lacks the productivity developed from cash dispensing by the ATMs. For, as a delivery medium that provides retail banking services even after banking hours it accrues consistent productivity for the bank. POS is an abbreviation for Point of Sale. The phrase is pertinent to a retail shop, the cashier/checkout counter in the location where such transactions can be done in this kind of environment (Jun and Cai, 2001).The design of Internet banking is, to give customers right of entry to their bank accounts through a web site and to allow them to carry out specific transactions on their account, given conformity with strict security checks (Essinger, 1999).

Internet Banking, which is viewed as the provision of traditional banking services over the internet, by its attributes offers more convenience and flexibility to customers joined with an almost absolute control over their banking. Service delivery is transactional (such as carrying out retail banking services) and informational (informing customers on bank's products, etc). The main objective of the study is to examine the effect of electronic service delivery channels on customer retention.

\subsection{Statement of the Problem}

Electronic channels of delivering banking services were brought into limelight in Nigeria due to frequent delays and long queues in the banking halls. Occasionally, a lot of customers out of persistent frustration and pointless delays do complain of the bank's operations. Some customers who are in need of immediate and fast service delivery leave the banking hall for other banks which they often view as providing fast-track banking services. The use of electronic channels of banking is increasing on daily basis. In this regard it is important to study the issues towards the use of these services in the Nigerian banking industry.

Although, electronic banking channels provide a tremendously useful service to bank customers, at times they can be very annoying to use and therefore there is still lots of opportunity for enhancement. The customers were facing different kinds of problems with which electronic channel such as machine complexity, machine breakdown, poor quality notes, network failure, unsuitable location, high frequency of use, safety and security appear to be the main problems often encountered. Customers seem not to like ATMs because of its visualization problem, fear of technology, impersonality, and unwillingness to change and adopt novel mode of delivery of service.

The Nigerian banking industry has been in operation for many decades serving customers within the country. However, given the nature of demand in the market, they are expected to do more particularly in service quality delivery as needed by their customers and other stakeholders in the industry. Despite the long existence of the industry, customers appear to be experiencing poor services, inconveniences and high costs of transactions while using banking halls. This seems to have led to poor customer retention, hence the reason why commercial banks introduced electronic banking systems. It is therefore vital to ascertain how customer retention can be enhanced via electronic banking services specifically in online banking, POS, and Mobile banking services. 


\subsection{Objectives of the Study}

The broad objective is to examine the effect of electronic service delivery channels on customer retention. The specific objectives are to:

i. ascertain the influence of online banking service on customer retention

ii. determine the effect of point-of-sales service on customer retention

iii. examine the extent to which mobile banking service affect customer retention

\section{The Literature}

\subsection{Conceptual Review}

\subsubsection{Electronic Service Delivery Channels}

A channel is a gateway for execution of a service. A channel can be a tool, an office, a media, or an application; it can be manipulated by customer's interaction or via a systematic front-end interface. The 'Electronic Delivery Channel (EDC)' approach emerged as a result of a pressing need to ensure appropriate management and communicating of scattered services, products, and/or commodities that were previously not following a systematic process flow (Owens and Anna, 2006). EDCs have evolved gradually and adapted to serve consumer needs at their convenience. EDC serves as an alternate to complement the existing delivery channels. At this stage, it cannot be seen as a replacement to the existing designed service delivery channels, but rather as a developed interface to leverage the use of any service that is also being offered via conventional channels. For more than two decades, EDC has demonstrated its capability to meet consumer's expectations by ensuring timeliness, accuracy and convenience in service $24 / 7$.

In the banking sector, Electronic Delivery Channels are channels for providing banking services directly to the customers. Ovum Analyst Findings (2013), stated that customers can perform banking transactions via their ATM, contact the bank's Call Center for any inquiry, access the digital Interactive Voice Response (IVR), carry out transactions via Internet Banking, and even on smartphones through mobile banking, etc. These channels have aided banks to cover a broad consumer-base across geographies. Electronic delivery channels, is defined as those channels that enlarge the reach of services beyond the traditional bank branch channel, have come into existence as a result of innovations in information and communication technology and a shift in customer expectations. EDCs are transformative in nature, accepting the demand for access to financial services "anytime, anywhere, anyhow". They depend highly on information and communication systems and devices ranging from ATMs to mobile phones, all of which support quick transmission of non-financial and financial information between the customer and financial services providers. New technologies enhances efficiency via reduce operational costs, automation and enhanced service quality by cutting down on waiting times and presenting more convenient access and abridged cost to the end-consumer (www.ifc.org/financialinclusionafrica).

EDCs guarantee the smooth flow of expected transactions and provide banks with greater profits with lesser operational expenses and transaction costs. "Channelize through channels" is the modern paradigm for banking today, which in earlier times depend solely on the branch network - where enlarging the business meant adding more branches at high real estate and licensing costs (Chinedu, Chima, and Emeka 2012). The evolution of Alternate Delivery Channels has changed the dynamics of the branch network. The traditional branch services which consist of Teller Services, Cheque/Cash deposits etc. have now shifted to other channels; EDCs have now become independent of branch to provide unique services including, Cheque/Cash withdrawal, Foreign Exchange services, Bill Payments, Funds Transfers and now even mobile top-ups. This great expansion of services has now made the customers more informed towards EDCs.

\subsubsection{Customer Retention}

Customer retention is the capability of an organization to retain its customers over a particular era of time. Customer retention has to do with the customers of the firm that tend to go back to, continue to purchase or in some other way not defect to another firm, or to non-use entirely. Subsequently, customers who stay with an organization for a longer term are seen as retained customers (Ang and Buttle, 2006). According to Trasorras et al., (2009) customer retention rates can be considered by using attitudinal data which mirrors the psychological and customers emotional attachment i.e. engagement, loyalty and adherence. Customer retention begins with the first contact a firm has with a customer and it is consistent throughout the whole lifetime of a relationship and successful retention efforts take this whole lifecycle into account. 
Dick and Basu (1994) view loyalty as the strength between repeat patronage and comparative attitude which occur from comparing a specific brand with competing brands. Anderson and Jacobson (2000) noted that customer loyalty is the outcome of a firm developing a benefit for customer so that they will improve their purchases from the firm. They stated that true loyalty is developed when the customer becomes a supporter of the firm without incentives. There are lots of factors that attempt to explain customer retention in service firms but this study specifically focused on service quality, satisfaction and value. Cronin, Brady and Hult, (2000) pointed out that when service quality, satisfaction and value are investigated separately as drivers of loyalty outcome behaviors, they consistently have a statistically significant impact on loyalty. This study extended the marketing theory relative to service quality, value and satisfaction as antecedents of customer retention in service firms.

Customer retention shows the willingness of a customer to remain with a particular firm and continue to enjoy its products or services despite the offerings of competitors. It measures the attrition rate on the company or its product/service. In the banking industry, retention rate is measured through the level of inactive and dormant accounts volume of the bank. Advocacy as means of measuring customer retention tries to check how willing the customers are to recommend the company's product or service to other users of that product/service. It shows how satisfied a customer is with the organization and its services. It takes a satisfied customer to win his/her advocacy to other prospects and clients. Though Advocacy and Retention are interrelated, there is still dissimilarity between the two. Advocacy preaches the brand, which does not necessarily mean or translate to purchase, while Retention requires the customer to actually engage in purchase of the company's product/service which is a true indication of customer satisfaction.

NPS (Net Promoter Score) is another simple way to measure customer retention. Like Advocacy, NPS measures how likely your customers are to recommend your firm and its product/services to a friend. Only a loyal customer will refer your organization to a friend. Customer lifetime value is another good measurement of customer retention. It shows how often a customer patronizes a specific brand and how long they remain a customer. There is a simple calculation that shows the true retention of your customer. Share of Wallet measures the proportions of your customers' total spend on a particular product/service category that come to you. In a competitive business where customers buy same product or service from different suppliers, the percentage of the customer's total expenditure on that product/service category that comes to you determines the value the customer has placed on your business. The higher your share of the wallet indicates the customer's loyalty to you. It's calculated as: customer spend / customer category spend.

\subsubsection{Online Banking Service and Customer Retention}

An online service refers to any information and services provided over the Internet. These services not only allow subscribers to communicate with each other, but they also provide unlimited access to information (Sheth and Sharma, 2005). Online service is the process of rendering services to consumers over the internet for purchases of tangible and intangible products. Consumers of such services visit web stores from the comfort of their homes and offices to make purchases (Ozuru and Emezi, 2016). According to Wan, Luk and Chow (2005), online services can range from simple to complex. A basic online service may support subscribers to achieve needed data via a search engine, while a multifaceted one might be an online mortgage application from a bank.

Online services provide a tool in which subscribers can interact with one another, either by taking part in online conferences (forums) or by exchanging e-mail messages (Udo, Bagchi, 2010). In addition, the service can connect users with an almost unlimited number of third-party information providers. According to Proomrow (2003), online services if not done properly may cause customer disloyalty, hence the significance of delivering efficient, effective and quality services with remarks and excellent customer experience.

Online banking service or internet banking is therefore an internet based platform provided by banks for easy interaction and rendering of services between the bank and its customers. The platform services as a two way communication platform between the bank and its clients and support the customers to perform most of their banking transactions via the web without having physical contact with the bank. This platform has become one great service delivery tool for banks that adopted it.

Online service entails delivery of tangible/intangible products to customers through the internet platform. Customer service on the web can take some forms such as providing search and comparison capabilities, answering customers inquires, allowing them to track order status, providing technical information to customers and placement of online orders, etc (Ozuru and Kalu, 2011). The use of internet or online services has improved the pattern consumers purchase products and services in Nigeria. The internet is now a platform that most online shops explore in order to beat competitors in a fierce competitive environment (Jomes et al, 2003). Better customer service equals good customer retention and good online business enterprises like airline industry to differentiate their services from their competitors. 
Online customers bring a complete new set of customer service prospect that has never existed with brick-and-mortar stores, customer expects easy way of buying and a fast delivery system.

\subsubsection{Point of Sales Service and Customer Retention}

The point of sale (POS) is the time and location where a retail transaction is completed. It is the point at which a consumer makes a payment to the seller in exchange for products or after offering a service. At the point of sale, the seller would write an invoice for the customer, which may be a cash register printout or otherwise write the amount owed by the customer and provide alternatives for the customer to make payment. After receiving payment, the seller most times issues a receipt for the transaction. Usually the receipt is printed, but it is highly being dispensed by electronic means.

One of the most effective techniques to enhance sales is by paying attention to what customers want and need. With a CRM-friendly POS system, firms can easily collect and keep track of customer preferences and buying histories and transmit them to CRM systems in real time. Not only does this information support firms to better target marketing campaigns and upsell at the point of sale, but it also lets them cater offerings to individuals or groups of customers to augment the customer experience. With the increasing comfort level of consumers with POS, technology is already prompting banks to begin looking at ways to augment self-checkout systems while the industry management continues to evaluate upgrade alternatives.

Lucas (2002) in his literature review concluded that time and convenience are among the most vital factors bank managers should consider when selecting and implementing checkout processes for their retail outlets. It can apply to the actual Point of Sale (POS) Hardware and Software consisting of but not limited to: receipt printers, touch-screen display, electronic cash register systems, barcode scanners, scales and pole displays.

\subsubsection{Mobile Banking Service and Customer Retention}

Mobile banking refers to the use of a Smartphone or other cellular device to perform online banking tasks while away from your personal computer, such as bill payment, monitoring account balances, transferring money between accounts and locating an ATM. Mobile banking is a service provided by a bank that permits its customers to perform a series of financial transactions distantly using a mobile device such as tablet or a mobile phone and using software, usually known as an app, provided by the bank for the aim. Mobile banking is always available on a 24-hour basis. Some banks have restrictions on which accounts may be accessed via mobile banking, as well as a limit on the amount that can be transacted (Tiwari, Buse and Herstatt, 2006b).

Mahdi and Mehrdad (2010) used chi-square to investigate the influence of mobile banking in Iran and their findings from the viewpoints of customers is that, mobile banking caused higher return to Iranians. In other words, Iran financial institutions provide services that the customers are gaining satisfaction with specific reference to the use of mobile banking. Mahdi and Mehrdad (2010) concluded that ATMs in banking sectors will make cash circulation decreases, the competence of banking sector will improve, as client banking costs decrease (less cash fees to pay), service provider/shop keeper costs will reduce, and bank costs decrease (less checking, cash storage and processing costs), and that customers don't have sufficient knowledge related to mobile banking in Iran.

In a similar study, Jayawardhena and Foley (2000) examined mobile banking as a new electronic service delivery channel contending that mobile banking may aid in overcoming the inherent demerits of traditional banks and it is very clear that if mobile banking is carried out successfully it leads to high volume of transactions. Larger banking groups are better placed to go online with mobile phones via an internet bank. Although, mobile internet banks can pursue an aggressive strategy to position them in the market, and quickly attract new clients with high yielding deposits, this seems less important for traditional banks, which have already reached a stable position in the market (Jayawardhena and Foley, 2000). Instead, large banks can better obtain the benefits of scale effects and obtain larger productivity, gains via cost reductions in branches and personnel (Jayawardhena and Foley, 2000). They so receive a more stable flow of income and so obtain a strategic advantage over other banks (Nickerson and Sullivan, 2003).

Transactions consisting of cash or documents such as cheques can not be carried out using mobile banking, and a customer have to visit an ATM machine for cash withdrawals and cash or cheque deposits. According to Tiwari, Buse and Herstatt (2007), mobile banking is different from mobile payments, which consist of the use of a mobile device to pay for products/services either at the point of sale or remotely, comparable in certain respects to the use of a credit or debit card to impact an EFTPOS payment.

Therefore, banks must innovate well and every innovation must be communicated effectively and attractively to their targeted market (Iftekhar, Schmiedel and Song, 2009). Customers prefer to deposit money into a system in which they can achieve a better payment service (Kemppainen, 2003 and 2008). Innovation improves the movements of 
deposits from checking accounts to money market deposit accounts, increases use of brokered deposits, and greater average wage rates for bank employees for click and mortar banks (Sushanta and Ho, 2006).

\subsubsection{Benefits of Electronic Banking Channels}

The technological change has brought about lots of benefits to the banking industry in Nigeria and the world at large. Some of these can be identified as convenience to banking, enhanced customer access and awareness, speedy or faster process and transmission of information, reduction of fraud levels and improved risk management. Other gains are world compliance that is, employing trends to provide seamless and customized services globally and easier marketing of banking services etc.

Katz-K, Larson, and Larson, (2011) in a study, discovered that the most vital factors encouraging consumers to use online banking and other banking channels like ATM, POS, Quick teller etc. are lower fees followed by decreasing paper work and human error, which consequently reduce disputes (Oliver., 2000). Taylor (2005) concluded that it was transforming customer attitudes rather than bank cost structures that determine the innovations in distribution channels; they added that banking halls can only be profitable when the part that prefers electronic channel is twice the size of the part preferring banking hall.

Ease of conducting banking service outside the branch official operating hours has been seen vital in cases of adoption of e-banking. Banks provide inexpensive contact to the bank 24 hours a day, customers convenient and seven days a week. Folkes, Koletsky and Graham, (2007) stated that each ATM could do the same, basically transactions, routine as do human tellers in branch offices, but at half the cost and with a four-to-one merit in productivity. Given that ICT is now becoming part of the banking industry in Nigeria, its role could not be completely seen as substitute for tellers in the banking hall. There are several times where the ATMs have failed to function thus making the customer not to be able to access the service.

Lucas (2002) found a positive correlation between convenience and alternative banking and remarked that the most important advantage for the bank is cost saving and for the customers the primary gain is convenience. Multi-functionality of an IT based services may be another attribute that satisfies consumer needs (Hui et al., 2008). A decrease in the extent of customers visiting banks with a rise in electronic channels of distribution will also reduce the queues in the branches (Thornton and White, 2001). Increased accessibility and availability of more self-service distribution channels support bank administration in limiting the expensive branch network and its associate staff overheads. Bank staff and office location that are used in this fashion may be used for other gainful ventures (Birch and Young, 2007). This finally leads towards enhanced customer satisfaction and the institution's base line (Thornton and White, 2001).

Alternative banking also increases competition within the banking system and also from non-bank financial institution (Rose, 2009). The Internet increases the potency of the consumer to make price comparisons across sellers quickly and easily. As a consequence, this pushes prices and margins downward (Berry, Parasuraman, and Zeithaml, 2005). Tom and Lucey (2005) stated that banks are responding to the Internet differently, and that those which view the Internet as a complement and substitute to traditional bank channels gained better communication and interactivity with customers. Dube-Rioux, Schmitt, and Leclerc, (2009) argued that the alternative banking extends the relationship with the customers through providing financial services right into the home or office of customers. The banks may also enjoy the advantages in terms of improved customers loyalty and satisfaction (Williams, 2000).

\subsection{Theoretical Review}

\subsubsection{Technology Acceptance Model (TAM)}

Theories and models used in studies related to the innovations, acceptance and use of new technology are many. For instance, concentrating on the technological issues, (Davis 1989) advances the Technology Acceptance Model (TAM). This model relates the customers' behavioural intentions and his/her ICT use. It is suggested that, the actual behaviour of a person is determined by his behavioural intention to use, which is in turn influenced by user's attitude toward and perceived usefulness of the technology. However attitude and perceived usefulness are both determined by ease of use. Adopting the TAM model requires the understanding of end-users requirements concerning usefulness and user friendliness (Pedersen, Leif, Methlie and Thorbjornsen, 2002). From this model, user friendliness and usefulness affect users' attitudes towards any service (ibid.). Davis (1989; 1993), thus suggest that it is important to value user requirements based on perceived usefulness and the user friendliness of the technology rather than other objective measure. Critiques of this model are directed to its inclination to the technological/technical aspects of the technology in question ignoring other factors such as social aspect of the users. In practice, setbacks such as limited 
time, ability, organizational limits and unconscious habits will limit the freedom to Wang, Wang, Lin and Tang (2003) were interested to identify the elements that firmly decides acceptance of internet banking by the users.

According to the Technology Acceptance Model (TAM), perceived ease of use and perceived usefulness indicators are claimed to be fundamental in firmly deciding the acceptance and use of various information technologies (IT). These claims may not fully explain the user's behaviour toward recently emerging IT, such as internet banking. Using the TAM as a theoretical framework, Wang et al. (2003) introduces "perceived credibility" as a new indicator that reflects the user's (customer) privacy and security concerns in the acceptance of internet banking. Wang et al. (2003) investigated the impact of computer self-efficacy on the intention to use internet banking. The outcome strongly aided the extended TAM in forecasting the intention of customers to employ internet banking. It also exhibits the significant impact of computer self-efficacy on behavioural intention via perceived credibility, perceived usefulness and perceived ease of use (Wang et al., 2003).

\section{Research Model and Hypotheses}

The main antecedents of electronic service delivery channels were analyzed within the context of the banking industry, which enabled us to conceptualized service delivery in that context. The dimensions that shape the employee perception of ESDC are denoted by online banking service, point of sales service and mobile banking service.

Good customer relations warrant customer to come back for more and less relations requires a customer service strategy that puts in place polices, services, software, hardware that enable customers feel confident when making online transactions. Online services are not done haphazardly, rather, it takes planning, organizing, implementation and control to enable the attainment of the organizational goals. Online customers do not need to queue up online or be bored by unnecessary web pages before getting what they want (Reynolds, 2004).

Thus we hypothesize that;

\section{$\mathrm{Ha}_{1}$ : There is a significant relationship between online banking service and customer retention}

Point of Sale Systems are utilized in several firms, ranging from hotels, restaurants, and hospitality businesses, casinos, stadiums, nail/beauty salons, and also the retail environments. In the most basic sense, if product/service can be exchanged for monetary value - a Point of Sale System can be used. Lucas (2002) found that demand is high for POS technology therefore, can reduce queue time in the bank and give customers convenience and control. In the attempt to meet this demand, bank managers in the banking industry are exploring different techniques and evaluating current technology in checkout systems to assist them to improve their current customer checkout process.

Thus we propose that;

\section{$\mathbf{H a}_{2}$ : Point of sales service has a significant relationship with customer retention}

According to Vaidya (2011), the types of financial transactions which a customer may transact via mobile banking consist of checking account balances, electronic bill payments, list of latest transactions and money transfers between customers. Some also ensure that copies of statements are downloaded and sometimes printed at the customer's home; and some banks charge a fee for sending hardcopies of bank statements. From the bank's perspective, mobile banking limits the cost of handling transactions by decreasing the need for customers to visit a bank branch for deposit transactions and non-cash withdrawal.

Thus we hypothesize that;

$\mathbf{H a}_{3}$ : There is a significant relationship between mobile banking service and customer retention 


\section{Electronic Service Delivery Channels}

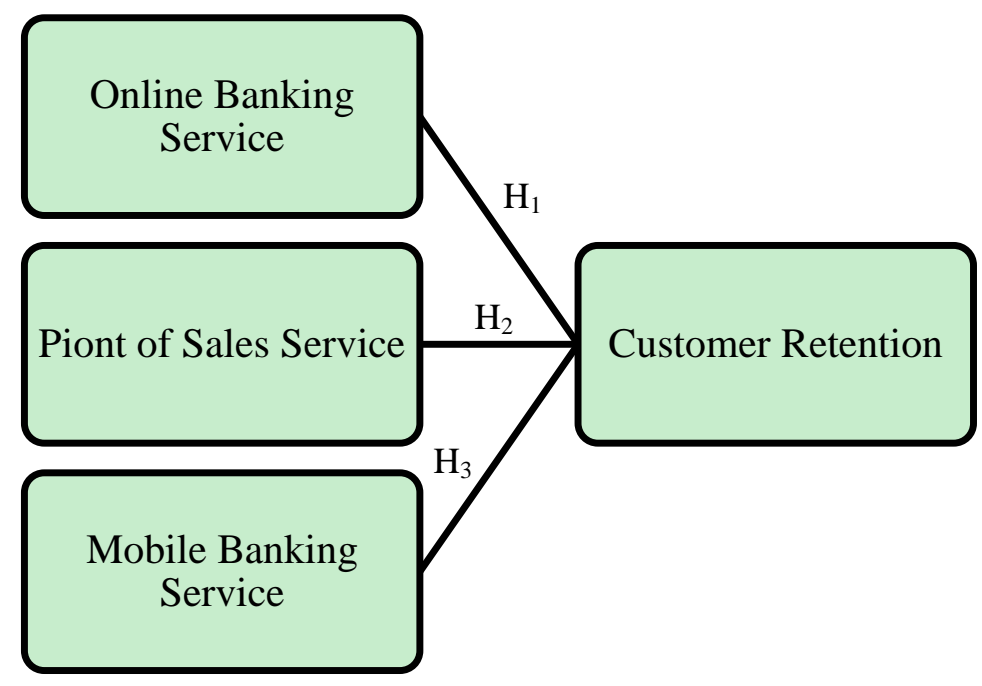

Figure 1. The Conceptual Model

Source: Researchers Model (2017)

\section{Methodology}

This study involved a field survey that examined electronic service delivery channels and customer retention in the Nigerian banking industry. The study is empirically based on primary data collected from bank employees in Asaba metropolis in Delta State, Nigeria. The participant of the study were 227 employees sampled through stratified random sampling techniques at different banks located in Asaba, Delta State based on availability and willingness of the participants. The research instrument was a 20 item validated structured questionnaire. Out of the 235 copies of structured questionnaire distributed, a total of 227 usable copies were collected giving a response rate of $97 \%$, implying a rate that is regarded as good. A majority of bank employees (52\%) were male. As to the educational qualification, $42 \%$ of the employees had obtained a university degree, $37 \%$ held diploma result and $21 \%$ held a postgraduate degree. Correlation and multiple regressions were used as the analytical tools in order to determine the level of effect the variables of electronic service delivery channels have on customer retention.

\subsection{Data Analysis}

Table 1. Correlation, reliability and descriptive statistics

\begin{tabular}{llllll}
\hline & & 1 & 2 & 3 & 4 \\
\hline 1 & Online Banking Service & 1 & & & \\
2 & Point of Sales Service & $.823^{* *}$ & 1 & & \\
3 & Mobile Banking Service & $.861^{* *}$ & $.867^{* *}$ & 1 & $.922^{* *}$ \\
4 & Customer Retention & $.873^{* *}$ & $.921^{* *}$ & 1 & 19.079 \\
& Mean & 19.181 & 19.141 & 19.145 & .9086 \\
& Standard deviation & .8297 & .8961 & .8678 & 0.814 \\
& Cronbach's alpha & 0.781 & 0.811 & 0.798 & \\
\end{tabular}

** Correlations are significant at .01 levels

Source: Analysis of Field Survey 2017 
Table 2. Model summary

Model Summary

\begin{tabular}{lrrrr}
\hline Model & R & R Square & $\begin{array}{c}\text { Adjusted R } \\
\text { Square }\end{array}$ & $\begin{array}{c}\text { Std. Error of the } \\
\text { Estimate }\end{array}$ \\
\hline 1 & $.958^{\mathrm{a}}$ & .918 & .916 & .2626 \\
\hline
\end{tabular}

a. Predictors: (Constant), mobile banking service, online banking service, point of sales service Source: Analysis of Field Survey 2017

Table 3. Results of multiple regressions of dimensions of electronic service delivery channels on customer retention

\section{Coefficients $^{\mathrm{a}}$}

\begin{tabular}{|c|c|c|c|c|c|c|}
\hline \multirow[b]{2}{*}{ Mod } & & \multicolumn{2}{|c|}{ Unstandardized Coefficients } & \multirow{2}{*}{$\begin{array}{c}\begin{array}{c}\text { Standardized } \\
\text { Coefficients }\end{array} \\
\text { Beta }\end{array}$} & \multirow[b]{2}{*}{$\mathrm{t}$} & \multirow[b]{2}{*}{ Sig. } \\
\hline & & B & Std. Error & & & \\
\hline \multirow[t]{4}{*}{1} & (Constant) & -.958 & .413 & & -2.321 & .021 \\
\hline & online banking service & .194 & .043 & .177 & 4.481 & .000 \\
\hline & point of sales service & .439 & .041 & .433 & 10.714 & .000 \\
\hline & mobile banking service & .413 & .047 & .394 & 8.730 & .000 \\
\hline
\end{tabular}

a. Dependent Variable: Customer Retention

Source: Analysis of Field Survey 2017

As indicated in the regression analysis table that examined the influence of OBS(online banking service), POSS (point of sales service), MBS on CR. It was revealed that OBS $(\beta=.177, \mathrm{P}<0.01), \mathrm{POSS}(\beta=.433, \mathrm{P}<0.01)$ and MBS (mobile banking service) $(\beta=.394, \mathrm{P}<0.01)$ exhibited significant positive effect on customer retention. The Adjusted $\mathrm{R}^{2}$ indicated that the three dimensions of the independent variable explained $92 \%$ of the variance in customer retention.

\section{Discussion of Findings}

The study examined the impact of electronic service delivery channels on customer retention in the banking industry in Asaba Metropolis Delta State, Nigeria. The results of the correlation analysis involving all components of electronic service delivery channels exhibited positive correlation coefficient values among the variables. This is an indication that they are appropriate dimensions and measures of electronic service delivery channels. The results from the multiple regression analysis reported the effect of electronic service delivery channels on customer retention

Specifically online banking service exhibited significant positive effect on customer retention $(\beta=.177, \mathrm{P}<0.01)$. The findings is in agreement with $\mathrm{H}_{1}$ test result $(\mathrm{r}=.000<.005)$ which showed that there is a significant relationship between online banking service and customer retention. This is consistent with the finding of Jomes et al, (2003) which established that the use of internet or online services has improved the pattern or changed the pattern of consumers purchase of products and services in Nigeria. They went further to state that the internet is now a platform that most online shop explores in order to beat competitors in a fierce competitive environment. This implies that the online banking service has enhanced the pattern at which customers pay for products and services.

Similarly the findings also indicated that point of sales service is found to have the relatively highest significant positive effect on customer retention $(\beta=.433, \mathrm{P}<0.01)$. The findings is in consonance with the test result of $\mathrm{H}_{2}$ $(\mathrm{r}=.000<.005)$ which reported that point of sales service has a significant positive relationship with customer retention. This is consistent with the view of Lucas (2002) that time and convenience are among the most vital factors bank managers should consider when selecting and implementing checkout processes for their retail outlets which POS offer to customers. The implication of this findings is that point-of-sale have become a tool that is used by banks to create convenience for customers to carry out transactions. 
Furthermore, the result of the regression analysis showed that mobile banking service has positive effect on customer retention $(\beta=.394, \mathrm{P}<0.01)$. This finding is in conformity with the result of $\mathrm{H}_{3}$ test $(\mathrm{r}=.000<.005)$ which exhibited that there is a significant relationship between mobile banking service and customer retention. This is in consonance with the finding of Jayawardhena and Foley (2000) that mobile banking as a new service delivery channel aid to overcome the intrinsic demerits of traditional banks and it is very clear that if mobile banking is done successfully it leads to high volume of transactions. This implies that if mobile banking is done successfully it will lead to high volume of transactions that will benefit both the banks and their customers.

\section{Conclusion}

Based on the findings from the foregoing analysis the following are the conclusion arrived at:

As an electronic delivery conduit for retail banking, it has all the influence on productivity imputed to Personal Computer-Banking and Tele-banking. And it seems to be the most cost-efficient technological channel of yielding greater productivity. Furthermore, it eradicates the challenges of time/distance and provides consistent productivity for the bank to inconceivable distant customers. Online customers bring several new set of customer service requirements that never existed with brick-and-mortar stores; customer expects easy way of buying and a fast delivery system. Therefore, quality customer service via online banking platform will foster good customer retention, hence, banks use this medium to gain competitive edge by ensuing that their online platforms are accessible and comprehensible.

The demand for POS technology appears currently high, therefore, banks tap into this opportunity by making POS available at all time, so as to reduce queue time in the bank and give customers convenience and control. With a CRM-friendly POS system, firms can easily gather and keep track of customer preferences and purchasing histories and broadcast them to CRM systems in real time. Not only does this information support firm better target marketing campaigns and upsell at the point of sale, but it also let them cater offerings to specific or groups of customers to enhance the customer experience.

Mobile banking is a new service delivery channel, that assist to conquer the intrinsic demerits of traditional banks and it is very clear that if mobile banking is carried out successfully it leads to high volume of transactions.

The multi-functionality of IT compliant banking service delivery medium has inherent attribute that enhances customer satisfaction, which fosters improved loyalty and customer retention. Thereby highlights the significance of this study in providing tremendous useful services to both concerned customers and banks: To the banks it appears to contribute a vast array of new solutions to effective services delivery challenges. It further fosters consistent productivity for the banks as a delivery medium that provides inexpensive contact of 24 hours services per a day and limits expensive branch network and its associated overheads. Finally to the customers, this service distribution channel provides expanded access, convenience, speedy process and time saving which help to ease the customers the stress of visiting and queuing up in the banking halls.

\section{Recommendations}

Banks should improve the uptime level of these platforms to sustain customer confidence on their use. Also, the channel applications should be made more users friendly. In the same note, effective co-operation among banks has to be developed. The value of internet banking is enhanced by connecting one activity with other both within and outside supplier, customers and channels.

Furthermore, banks should work together with internet service providers because it will help banks to better control quality of service as well as enhance user's accessibility. In addition, a high quality internet tools should be provided since it is one of the primary criteria for internet usage. Hence, banks should invest heavily in getting the required technological facilities so as to be able to satisfy their customers.

Finally, support from the government and the industry regulators should be effective to increase the growth of online/internet banking.

\section{References}

Anderson, H., \& Jacobsen, P.Q. (2000). Creating Loyalty: Its strategic importance in your customer strategy. S.A., 55-67.

Ang, L., \& Buttle, F. (2006). Customer retention management processes - a quantitative study. European Journal of Marketing, 40(1/2), 83-99. https://doi.org/10.1108/03090560610637329

Berry, L.L., Parasuraman, A., \& Zeithaml, V.A. (2005). Quality counts in services too. Business Horizons. 
Birch, B., \& Young, A. (2007). The business and technology history of automated teller machine in the UK, 1967-2005. A Primer Conference Abstracts, 16-17th June. Queen Mary University of London.

Chinedu, N. O., Chima, B. O., \& Emeka, E. I. (2012). Analysis of the Negative Effects of the Automated Teller Machine (ATM): As a Channel for Delivering Banking Services in Nigeria. International Journal of Business and Management, 7(7).

Cronin, J., Brady M., \& Hult, G.T. (2000). Assessing the effects of quality, value and customer satisfaction on consumer behavioral intentions in service environment. J. Retail., 76(2), 193-218. https://doi.org/10.1016/S0022-4359(00)00028-2

Davis, F. D. (1989). Perceived Usefulness, Perceived Ease of use, and user acceptance of information technology. MIS Quarterly, 13(3), 319-340. https://doi.org/10.2307/249008

Davis, F.D. (1993). User Acceptance of information technology: system characteristics, user perceptions and behavioral impacts. International Journal of Man-Machine Studies, 38(3), 475-487. https://doi.org/10.1006/imms.1993.1022

Dick, A.S., \& Basu, K. (1994). Customer loyalty: Toward an Integrated Conceptual Framework. J. Acad. Mark. Sci., 22, 99-113. https://doi.org/10.1177/0092070394222001

Dube-Rioux, L., Schmitt, B., \& Leclerc, F. (2009). Consumer's Reactions to Waiting: When Delays Affect the Perception of Service Quality. Advances in Consumer Research (16 ed.). Thomas K. Srull, (Ed.), Provo, UT: Association for Consumer Research, pp. 59-63.

Essinger, J. (1999). The Virtual Banking Revolution: The Customer, the Bank and the Future (1st ed.). International Thomson Business Press, London, UK,

Folkes, V., Koletsky, S., \& Graham, J.L. (2007). A Field Study of Causal Inferences and Consumer Reaction: The View from the Airport. Journal of Consumer Research, 13, 534-39. https://doi.org/10.1086/209086

Hui, M.K., Thakor, M.V., \& Gill, R. (2008). The effect of delay type and service stage on consumers' reactions to waiting. Journal of Consumer Research, 24(4), 469-479. https://doi.org/10.1086/209522

Iftekhar, H., Schmiedel, H., \& Song, L. (2009). Return to retail banking and payments. Working Paper Series 1135, European Central Bank.

Jayawardhena, C., \& Foley, P. (2000). Changes in the banking sector: The case of internet banking in the UK. Internet Research: Electronic Networking Applications and Policy, 10(1), 19-30. https://doi.org/10.1108/10662240010312048

Jun, M., \& Cai, S. (2001). The key determinants of internet banking service quality: a content analysis. The International Journal of Bank Marketing, 19(7), 276-91. https://doi.org/10.1108/02652320110409825

Katz, K. L., Larson, B. M., \& Larson, R.C. (2011). Prescription for the waiting in line blues: entertain, enlighten, and engage. Sloan Management Review, Winter, 32(2), 44-53.

Kemppainen, K. (2003). Competition and regulation in European retail payment systems. Bank of Finland Discussion Papers. https://doi.org/10.2139/ssrn.421903

Kemppainen, K. (2008). Integrating European Retail Payment Systems: Some Economics of SEPA. Bank of Finland Discussion Papers. https://doi.org/10.2139/ssrn.1299614

Kumar, V., Andrew, J.P., \& Robert, P.L. (2007). How valuable is word of mouth? Harvard Business Review, 85(10), 139-146.

Leow, H. B. (1999). New Distribution Channels in banking Services. Banker's Journal Malaysia, (110), 48-56.

Lucas, P. (2002, March). Self service at the point of sale. Credit Card Management, New York, 14(13), 30.

Mahdi, S., \& Mehrdad, A. (2010). E-banking in emerging economy: Empirical evidence of Iran. International Journal of Economics and Finance, 2(1), 201-209.

Mwangi, J. (2007). Equity Bank: Alternate Delivery Channels [Presentation]. Retrieved from http://siteresources.worldbank.org/FSLP/Resources/Equity-NextGenerationConference.ppt

Oliver, R.L. (2000). A cognitive model of the antecedents and consequences of satisfaction decision, Journal of Marketing Research, 17, 460-9. https://doi.org/10.2307/3150499 
Ovum Analyst Research. (2013). European Retail Banking Investment Strategies. The Himalayan Times. Retrieved from http://www.thehimalayantimes.com/ fullNews.php?headline=Dollar+at+historic+high\&NewsID=381744

Owens, J., \& Anna, B. (2006). Catching the Technology Wave: Mobile Phone Banking and Text-A-Payment in the Philippines.

Ozuru, H. N., \& Emezi, P. I. (2016). Online Services Characteristics and Customer Loyalty in Airline Industry in Port Harcourt, Rivers State. Haitian Research Journal on Development Studies (HRJS), 14(1).

Pedersen, P., Methlie, L., \&Thorbjornsen, H. (2002). Understanding mobile commerce end-user adoption: a triangulation perspective and suggestions for an exploratory service evaluation framework. Proceedings of the 35th Hawaii International Conference on System Sciences. https://doi.org/10.1109/HICSS.2002.994011

Rose, M.A. (2009). An empirical study of ATM service quality and customer satisfaction in Pakistani banks. European Journal of Social Sciences, 13(3), 333-343.

Sheth, J., \& Sharma, A. (2005). International E-Marketing: Opportunities and Issues. International Marketing Review, 22(6), 611-622. https://doi.org/10.1108/02651330510630249

Shu, W., \& Strassmann, P. A. (2005). Does information technology provide banks with profit?. Information and Management, 42(5), 781-787. https://doi.org/10.1016/j.im.2003.06.007

Taylor, S. (2005). The effects of filled waiting time and service provider control over the delay on evaluations of service. Journal of the Academy of Marketing Science, 23, 38-48. https://doi.org/10.1007/BF02894610

Thornton, K.S., \& White, G.R (2001). Speech technology for automatic teller machines: An investigation of user attitude and performance. Ergonomics, 41(7), 962-981.

Tiwari, R., Buse, S., \& Herstatt, C. (2006b). Mobile Banking as Business Strategy: Impact of Mobile Technologies on Customer Behaviour and its Implications for Banks. In Technology Management for the Global Future Proceedings of PICMET '06.

Tiwari, R., Buse, S., \& Herstatt, C. (2007). The Mobile Commerce Prospects: A Strategic Analysis of Opportunities in the Banking Sector. Hamburg University Press (E-Book as PDF to be downloaded).

Tom, G., \& Lucey, S. (2005). Waiting time delays and customer satisfaction in supermarkets, Journal of Services Marketing, 9(5), 20-9. https://doi.org/10.1108/08876049510100281

Trasorras, R., Weinstein, A., \& Abratt, R. (2009). Value, satisfaction, loyalty and retention in professional services. Marketing Intelligence \& Planning, 27(5), 615-632. https://doi.org/10.1108/02634500910977854

Udo, Godwin J., Kallol K. Bagchi, \& Peeter J. Kirs. (2010). An assessment of customers' e-service quality perception, satisfaction and intention. International Journal of Information Management, 30, 481-492. https://doi.org/10.1016/j.ijinfomgt.2010.03.005

Vaidya. (2011). Emerging Trends on Functional Utilization of Mobile Banking in Developed Markets in Next 3-4 Years.

Wan, W. W. N., Luk, C. L., \& Chow, C. W. C. (2005). Customers' adoption of banking channels in Hong Kong. International Journal of Bank Marketing, 23(3). https://doi.org/10.1108/02652320510591711

Wang, Y.S., Wang, Y.M., Lin, H.H., \& Tang, T.I. (2003). Determinants of user acceptance of internet banking: an empirical study. International Journal of Service Industry Management, 14(5), 501-519. https://doi.org/10.1108/09564230310500192

William, A. (2000). Computerization or Automation of banking systems in Ghana, The way forward. The school of business, MalardaleneHogskolan, Sweden. 